\title{
PERBANDINGAN GANTI RUGI DAN MEKANISME PERALIHAN HAK MENURUT PERATURAN PRESIDEN NOMOR 65 TAHUN 2006 DAN UNDANG-UNDANG NOMOR 2 TAHUN 2012
}

\author{
Aristya Windiana Pamuncak, SH., LLM, MH. ${ }^{1}$ \\ awp188@ums.ac.id
}

\begin{abstract}
$L$ egislation regarding land procurement for public interest is always aligned to the needs of the times. there are fundamental differences that change the course, especially in the areas of compensation and the mechanism of transfer of rights in Presidential Decree No. 65 year 2006 and Law No. 2 Year 2012. This research is normative juridical and using secondary data. Research shows that Act No. 2 Year 2012 stipulates that compensation should be fair and reasonable, while Presidential Decree No. 65 of 2006 stipulates that compensation should lead to a better condition than the previous situation. In the case of the transitional mechanism of land rights, Law No. 2 year 2012 gave rise to a consignment on compensation where the Presidential Decree No. 65 year 2006 set by the revocation of land rights in accordance with the Act of Agraria.
\end{abstract}

Keyword: Land Procurement, Public Interest

\begin{abstract}
ABSTRAK
$\mathrm{P}$ eraturan perundang-undangan mengenai pengadaan tanah untuk kepentingan umum selalu diupayakan agar sesuai dengan kebutuhan zaman. terdapat perbedaan mendasar yang mengubah haluan khususnya dalam bidang ganti rugi dan mekanisme peralihan hak dalam Perpres Nomor 65 Tahun 2006 dan UU No 2 Tahun 2012. Artikel ini bertujuan untuk menelaah bagaimana perbedaan pengaturan pemberian ganti rugi dalam Peraturan Presiden Nomor 65 Tahun 2006 dan Undang-Undang Nomor 2 Tahun 2012 dengan menggunakan metode penelitian normatif yuridis dan menggunakan data skunder. Artikel menunjukkan UU Nomor 2 Tahun 2012 mengatur bahwa ganti rugi harus adil dan layak, sementara Perpres Nomor 65 Tahun 2006 mengatur bahwa ganti rugi harus menimbulkan keadaan yang lebih baik dari keadaan sebelumnya. Dalam hal mekanisme peralihan hak atas tanah, UU Nomor 2 Tahun 2012 memunculkan konsinyasi atas uang ganti rugi dimana dalam Perpres Nomor 65 Tahun 2006 mengatur melalui pencabutan hak atas tanah sesuai dengan UU Agraria
\end{abstract}

Kata Kunci: Pengadaan Tanah, Kepentingan Umum

\section{PENDAHULUAN}

Tanah sangat dibutuhkan dalam pembangunan baik pembangunan untuk kepentingan umum maupun swasta. Saat ini, pembangunan terus meningkat sedangkan luas tanah selalu tetap. Dalam melaksanakan pembangunan terutama untuk kepentingan umum, sering sekali menggunakan tanah yang berasal dari masyarakat. Tanah masyarakat tersebut dapat digunakan untuk keperluan pembangunan melalui proses pengadaan tanah untuk kepentingan umum.

Landasan hukum pengadaan tanah selalu diperbarui dari waktu ke waktu. Presiden menerbitkan Peraturan Presiden Nomor 65 Tahun 2006 yang merupakan perubahan dari Peraturan Presiden Nomor 36 tahun 2005. Peraturan pelaksana perpres tersebut adalah peraturan kepala BPN Nomor

1 Dosen Pengajar Di Fakultas Hukum Universitas Muhammadiyah Surakarta 
3 Tahun 2007 tentang Ketentuan Pelaksana Peraturan Presiden Nomor 36 Tahun 2005 tentang Pengadaan Tanah Bagi Pelaksanaan Pembangunan Untuk Kepentingan Umum Sebagaimana Telah Diubah Dengan Peraturan Presiden Nomor 65 Tahun 2006 tentang Perubahan Atas Peraturan Presiden Nomor 36 Tahun 2005 tentang Pengadaan Tanah Bagi Pelaksanaan Pembangunan Untuk Kepentingan Umum.

Pemerintah dan DPR RI menghadirkan peraturan pengadaan tanah yang diharapkan ideal dalam sidang Paripurna tanggal 16 Desember 2011, maka lahirlah Undang-undang Nomor 2 Tahun 2012 tentang Pengadaan Tanah Bagi Pembangunan Untuk Kepentingan Umum yang disahkan pada tanggal 14 Januari 2012. Peraturan pelaksanaan dari UU tersebut adalah Perpres Nomor 71 Tahun 2012 tentang Penyelenggaraan Pengadaan Tanah bagi Pembangunan untuk Kepentingan Umum juncto Peraturan Presiden Nomor 40 Tahun 2014 tentang Perubahan atas Peraturan Presiden Nomor 71 Tahun 2012 tentang Penyelenggaraan Pengadaan Tanah bagi Pembangunan untuk Kepentingan Umum. Peraturan-peraturan baru tersebut diharapkan dapat menjadi landasan hukum yang memperbaiki pelaksanaan pengadaan tanah untuk pembangunan. Untuk melaksanakan Perpres tersebut di buatlah Peraturan Kepala Badan Pertanahan Nasional Nomor 5 Tahun 2012 tentang Petunjuk Teknis Pelaksanaan Pengadaan Tanah.

Walaupun peraturan perundang-undangan terkait pengadaan tanah untuk kepentingan umum telah diupayakan sesuai perkembangan zaman, masih banyak pandangan dari praktisi maupun akademisi yang bernada negatif. Untuk melihat baik tidaknya suatu peraturan dapat menggunakan sebagian teori efektivitas hukum. Faktor-faktor yang mempengaruhi efektivitas hukum menurut Soerjono Soekanto adalah: faktor hukumnya sendiri, faktor penegak hukum, faktor sarana atau fasilitas, faktor masyarakat, faktor budaya.

Mengingat penulis membatasi pada penelitian normatif mengenai peraturan-perundangannya saja, maka penulis hanya membatasi pada faktor hukumnya saja. Faktor hukum atau peraturan perundang-undangan adalah faktor pertama dan utama terciptanya efektivitas hukum. ${ }^{2}$ Salah satu elemen yang patut dipertanyakan adalah apakah peraturan yang ada mengenai bidang-bidang kehidupan tertentu sudah cukup sinkron secara hierarki dan secara horizontal tidak ada pertentangan

Untuk melihat apakah Peraturan Presiden Nomor 65 Tahun 2006 dan Undang-Undang Nomor 2 Tahun 2012 sudah sudah cukup sinkron secara hierarki dan secara horizontal tidak ada pertentangan, maka perlu dilakukan kajian lebih mendalam yang berjudul, "Perbandingan Ganti Rugi Dan Mekanisme Peralihan Hak Menurut Peraturan Presiden Nomor 65 Tahun 2006 Dan Undang-Undang Nomor 2 Tahun 2012 ”.

\section{RUMUSAN MASALAH}

Berdasarkan uraian dari latar belakang masalah di atas, serta untuk lebih terarahnya sasaran dari penulisan ini, maka penulis akan mendalami pada permasalahan bagaimana pengaturan pemberian ganti rugi dalam Peraturan Presiden Nomor 65 Tahun 2006 dan Undang-Undang Nomor 2 Tahun 2012?

\section{PEMBAHASAN}

\section{Pengertian Ganti Rugi}

Konsep ganti rugi yang terdapat di dalam Hukum Perdata, diartikan sebagai pembayaran kerugian yang diderita oleh seseorang karena adanya perbuatan wanprestasi/ingkar janji. ${ }^{3}$ Dapat juga diartikan sebagai pemberian prestasi yang setimpal akibat dari satu perbuatan yang menyebabkan kerugian yang diderita oleh salah satu pihak yang melakukan kesepakatan/ konsensus. ${ }^{4}$ Pengertian Ganti rugi menurut Sudikno adalah pemberian ganti atas kerugian

2 Soerjono Soekanto, 1983. Penegakan hukum bandung: Bina Cipta hal 80

3 Subekti, 1979. Hukum Perjanjian Cetakan ke-VI. Jakarta: PT. Intermedia. hal. 45

$4 \quad$ Subekti ibid, hal. 45 
yang diderita oleh pemegang hak atas tanah atas beralihnya hak tersebut. ${ }^{5}$ Sedangkan R. Subekti, menyatakan bahwa:

"Yang dimaksudkan kerugian yang dapat dimintakan penggantian itu, tidak hanya berupa biaya-biaya yang sungguh-sungguh telah dikeluarkan (konsten), atau kerugian yang sungguh-sungguh menimpa harta benda si berpiutang (schaden), tetapi juga berupa kehilangan keuntungan (interessen), yaitu keuntungan yang akan didapat seandainya si berhutang tidak lalai (winstderving)." ${ }^{\prime 6}$ Supriadi memberikan batasan bahwa ganti rugi meliputi beberapa aspek yaitu :

a. Kesebandingan, yaitu ukuran untuk kesebandingan antara hak yang hilang dengan penggantinya harus adil menurut hukum dan menurut kebiasaan masyarakat yang berlaku umum.

b. Kelayakan, selain sebanding ganti rugi harus layak jika penggantian dengan hal lain yang tidak memiliki kesamaan dengan hak yang telah hilang.

c. Perhitungan cermat, perhitungan harus cermat termasuk didalamnya penggunaan waktu, nilai dan derajat. Dalam hal pengadaan tanah, ganti rugi adalah dasar perhitungan dalam melakukan pembayaran ganti kerugian atas hak tanah yang akan diambil untuk pembangunan kepentingan umum. ${ }^{7}$

Maria S. W. Soemardjono, menekankan satu hal dalam ganti rugi, yaitu prinsip keadilan dimana transaksi jual beli tanah yang berkeadilan adalah jika hasil yang diperoleh oleh pihak yang berhak minimal setara dengan ketika tanahnya belum dibeli Pemerintah. idealnya peraturan mengatur agar pemilik tanah bisa dilindungi seperti melalui pemberian ganti rugi yang sesuai dimana dalam pemberian ganti rugi jangan mengakibatkan kemunduran ekonomi, status sosial maupun tingkat hidup masyarakat pemilik tanah. ${ }^{8}$

Dasar pemberian ganti rugi terdapat dalam Pasal 18 UUPA yang berbunyi:“Untuk kepentingan umum, termasuk kepentingan bangsa dan Negara serta kepentingan bersama dari rakyat, hak-hak atas tanah dapat dicabut, dengan memberi ganti kerugian yang layak dan menurut cara yang diatur dengan Undang-undang". Dalam penjelasan pasal 18 dinyatakan bahwa pasal tersebut merupakan jaminan bagi rakyat mengenai hak-haknya atas tanah. Pencabutan hak dimungkinkan, tetapi diikat dengan syarat-syarat yang diatur menurut Undang-Undang.

Pengertian ganti rugi disebut secara tegas dalam Peraturan Presiden Nomor 36 Tahun 2005 Juncto Peraturan Presiden Nomor 65 Tahun 2006, Pasal 1 angka 11 menyatakan bahwa Ganti kerugian adalah penggantian terhadap kerugian baik bersifat fisik dan/atau non fisik sebagai akibat pengadaan tanah kepada yang mempunyai tanah, bangunan, tanaman, dan/atau benda-benda lain yang berkaitan dengan tanah yang dapat memberikan kelangsungan hidup yang lebih baik dari tingkat kehidupan sosial ekonomi sebelum terkena pengadaan tanah.

Pengertian ganti rugi menurut Pasal 1 angka 10 Undang-Undang No 2 Tahun 2012 yang menyatakan ganti kerugian adalah penggantian yang layak dan adil kepada pihak yang berhak dalam proses pengadaan tanah. Kata "layak dan adil" tidak ada penjelasan yang spesifik, namun dalam penjelasan Pasal 2 Huruf b memperjelas asas keadilan yaitu memberikan jaminan penggantian yang layak kepada Pihak yang Berhak dalam proses Pengadaan Tanah sehingga mendapatkan kesempatan untuk dapat melangsungkan kehidupan yang lebih baik.

Sudikno Mertokusumo. 2007. Mengenal Hukum Suatu Pengantar, Revisi Ketiga. Yogyakarta: Liberty, hal. 45.

R. Subekti. 1985. Pokok-pokok Hukum Perdata. Jakarta: PT. Intermasa halaman 148

Supriadi. 2009. Hukum Agraria. Sinar Grafika: Jakarta. hal 80

Muhadar, 2006. Viktimisasi Kejahatan Pertanahan, Cetakan ke II, Edisi Revisi, Yogyakarta: LaksBang PRESSindo hal. 61-62 
Penekanan maksud dan makna yang sangat berbeda dengan Peraturan Presiden Nomor 65 Tahun 2006 dimana kalimat "memberikan kelangsungan hidup yang lebih baik dari tingkat kehidupan sosial ekonomi sebelum terkena pengadaan tanah" disebut secara tegas di dalam Pasal. Unsur nilai yang terkandung yang menjadi tujuan dalam pasal tersebut terdiri dari kelangsungan hidup yang lebih baik dan dari tingkat kehidupan sosial ekonomi sebelum terkena pengadaan tanah. Unsur nilai yang terkandung tegas dan spesifik.

Adapun dalam No 2 Tahun 2012 nilai yang dituju adalah adil dan layak, dimana masih sangat abstrak. Hal ini karena ukuran kelayakan tentu bisa sangat relatif dan subjektif. Dalam penjelasan, kandungan nilai yang menjadi tujuan adalah "mendapatkan kesempatan" dan "dapat melangsungkan kehidupan yang lebih baik". Nilai "mendapatkan kesempatan" dan "kehidupan yang lebih baik" sangat tidak spesifik maksud dan maknanya. Berdasarkan uraian tersebut, maka dapat disimpulkan bahwa telah terjadi penurunan itikad menyejahterakan rakyat yang tersebut dalam hal prinsip ganti kerugian.

\section{Objek Kerugian}

Objek ganti rugi, yaitu tanah, bangunan, tanaman dan benda-benda lain yang berkaitan dengan tanah. Pengertian benda-benda lain yang berkaitan dengan tanah berarti bersifat fisik atau kebendaan, atau kasat mata. Benda-benda tersebut misalnya adanya sumur sebagai sumber air, tempat jemur di penggilingan padi, mesin-mesin pabrik, gudang dll. Padahal, selain kerugian yang sifatnya kebendaan, terdapat kerugian lain yang sifatnya bukan fisik atau nonfisik. Dalam Perpres Nomor 36 Tahun 2005 jo Perpres Nomor 65 Tahun 2006, pengertian ganti rugi sebagaimana telah disebut diatas, telah mengakomodasi kerugian-kerugian non fisik yang ditimbulkan karena pengadaan tanah. Namun demikian, tidak ditemukan objek ganti rugi dalam Pasal 12. Pasal tersebut sama sekali tidak menyinggung mengenai kerugian non fisik. Ganti rugi dalam rangka pengadaan tanah diberikan untuk: hak atas tanah, bangunan, tanaman, dan benda-benda lain yang berkaitan dengan tanah.

\section{Mekanisme Peralihan Hak Atas Tanah}

Dalam hal lokasi pengadaan tanah tidak dapat dialihkan ke lokasi lain karena sebab tertentu sebagaimana disebut diatas, maka sesuai Pasal 10 ayat (1) musyawarah dilakukan dalam jangka waktu paling lama 120 (seratus dua puluh) hari kalender terhitung sejak tanggal undangan pertama. Waktu yang lebih lama, diharapkan dapat memberi waktu yang cukup untuk bernegosiasi. Apabila dalam waktu 120 hari diperoleh kesepakatan harga antara pemegang hak atas tanah dan instansi Pemerintah dan/atau pemerintah daerah yang memerlukan tanah, maka sesuai Pasal 11 panitia pengadaan tanah mengeluarkan keputusan mengenai bentuk dan besarnya ganti rugi sesuai dengan kesepakatan tersebut.

Dalam hal telah habis masa musyawarah dan tidak terjadi mufakat, maka sesuai Pasal 10 ayat 2, panitia pengadaan tanah menetapkan besarnya ganti rugi sebagaimana dimaksud dalam Pasal 13 huruf a dan menitipkan ganti rugi uang kepada pengadilan negeri yang wilayah hukumnya meliputi lokasi tanah yang bersangkutan.pihak yang berhak yang merasa keberatan dengan Keputusan panitia pengadaan tanah tentang penetapan besarnya ganti rugi tersebut dapat mengajukan upaya hukum berupa keberatan atas nilai besaran ganti rugi kepada Bupati/Walikot atau Gubernur atau Menteri Dalam Negeri. Hal tersebut diatur dalam Pasal 17 yang berbunyi sebagai berikut:

1) Pemegang hak atas tanah yang tidak menerima keputusan panitia pengadaan tanah dapat mengajukan keberatan kepada Bupati/Walikota atau Gubernur atau Menteri Dalam Negeri sesuai kewenangan disertai dengan penjelasan mengenai sebab-sebab dan alasan keberatan tersebut.

2) Bupati/Walikota atau Gubernur atau Menteri Dalam Negeri sesuai kewenangan mengupayakan penyelesaian mengenai bentuk dan besarnya ganti rugi tersebut dengan 
mempertimbangkan pendapat dan keinginan dari pemegang hak atas tanah atau kuasanya. 3) Setelah mendengar dan mempelajari pendapat dan keinginan pemegang hak atas tanah serta pertimbangan panitia pengadaan tanah, Bupati/Walikota atau Gubernur atauMenteri Dalam Negeri sesuai kewenangan mengeluarkan keputusan yang dapat mengukuhkan atau mengubah keputusan panitia pengadaan tanah mengenai bentuk dan/atau besarnya ganti rugi yang akan diberikan."

Berdasarkan pada Pasal 17 ayat (2) diatur bahwa Bupati/Walikota atau Gubernur atau Menteri Dalam Negeri akan mempertimbangkan pendapat dari pihak yang berhak kemudian akan mengeluarkan putusan mengenai bentuk dan/atau besarnya ganti rugi yang akan diberikan. Hingga pada tahap ini, apabila pemegang hak atas masih keberatan dengan nilai ganti rugi yang diputuskan, maka akan berlanjut ke presiden dan untuk memberikan Keppres mengenai bentuk dan/atau besarnya ganti rugi sesuai yang diatur dalam UU No 20 Tahun 1961 yang didahului dengan pencabutan hak atas tanah. Oleh karena itu, dalam UU tersebut terdapat mekanisme melibatkan tandatangan kepala BPN, menteri dalam negeri dan menteri hukum dan HAM yang bertanggungjawab memberikan saran kepada presiden sebelum pencabutan hak atas tanah dilakukan.

Hal tersebut merupakan upaya kehati-hatian karena berkaitan dengan hak asasi warga negara yaitu hak untuk memiliki. Ketentuan mengenai pencabutan hak atas tanah tersebut diatur dalam Pasal 18, yangberbunti sebagai berikut:

1) Apabila upaya penyelesaian yang ditempuh Bupati/Walikota atau Gubernur atau Menteri Dalam Negeri tetap tidak diterima oleh pemegang hak atas tanah dan lokasi pembangunan yang bersangkutan tidak dapat dipindahkan, maka Bupati/Walikota atau Gubernur atau Menteri Dalam Negeri sesuai kewenangan mengajukan usul penyelesaian dengan cara pencabutan hak atas tanah berdasarkan Undang-undang Nomor 20 Tahun 1961 tentang Pencabutan Hak-hak Atas Tanah Dan Benda-benda Yang Ada Di Atasnya.

2) Usul penyelesaian sebagaimana dimaksud pada ayat (1) diajukan oleh Bupati/Walikota/ Gubernur/Menteri Dalam Negeri sesuai kewenangan kepada Kepala Badan Pertanahan Nasional dengan tembusan kepada menteri dari instansi yang memerlukan tanah dan Menteri Hukum dan Hak Asasi Manusia.

3) Setelah menerima usul penyelesaian sebagaimana dimaksud pada ayat (1) dan ayat (2), Kepala Badan PertanahanNasional berkonsultasi dengan menteri dari instansi yang memerlukan tanah dan Menteri Hukum dan Hak Asasi Manusia.

4) Permintaan untuk melakukan pencabutan hak atas tanah tersebut disampaikan kepada Presiden oleh Kepala Badan Pertanahan Nasional yang ditandatangani oleh menteri dari instansi yang memerlukan tanah, dan Menteri Hukum dan Hak Asasi Manusia.”

Hingga tahap ini, apabila pihak yang berhak masih tidak bersedia menerima ganti rugi karena nilainya kurang layak, maka yang bersangkutan masih memiliki upaya hukum terakhir yaitu dengan meminta banding kepada pengadilan tinggi. Pengadilan tinggi tersebut hanya akan memutuskan besaran nilai ganti rugi saja, dan bukan memutuskan untuk mencabut hak atas tanah. Hal ini karena pencabutan hak atas tanah bukan kewenangan pengadilan tinggi melainkan kewenangan presiden sebagai perwakilan bangsa Indonesia. Upaya hukum banding tersebut diatur dalam Pasal 18A yang berbunyi sebagai berikut:

"Apabila yang berhak atas tanah atau benda-benda yang ada di atasnya yang haknya dicabut tidak bersedia menerima ganti rugi sebagaimana ditetapkan dalam Keputusan Presiden, karena dianggap jumlahnya kurang layak, maka yang bersangkutan dapat meminta banding kepada Pengadilan Tinggi agar menetapkan ganti rugi sesuai Undang-Undang Nomor 20 Tahun 1961 tentang Pencabutan Hak-Hak Atas Tanah dan Benda-Benda yang Ada di Atasnya dan Peraturan Pemerintah Nomor 39 Tahun 1973 
tentang Acara Penetapan Ganti Kerugian oleh Pengadilan Tinggi Sehubungan dengan Pencabutan Hak-Hak Atas Tanah dan Benda-Benda yang ada di Atasnya."

Berbeda dengan Perpres No 36 Tahun 2005 jo Perpres No 65 Tahun 2006, Upaya hukum atas keberatan nilai besaran ganti rugi dalam Undang-Undang No 2 Tahun 2012 sama sekali tidak melibatkan Presiden maupun mendasarkan pada UU No 20 Tahun 1961. UndangUndang memiliki start yang sama dalam arti bermula dari musyawarah, namun memiliki finish yang berbeda. Perbedaan tersebut terjadi ketika upaya keberatan tersebut berujung di pengadilan dan bukan ditangan Presiden. Pada saat dipengadilan terakhir hak atas tanah beralih dari pihak yang berhak kepada pemerintah/instansi pemerintah yang membutuhkan. Kejanggalan ini di bahas oleh banyak sarjana hukum bahwa pengalihan hak atas tanah dalam Undang-undang tersebut tidak linear dengan sistem yang selama ini berlaku.

Upaya hukum keberatan besaran ganti rugi bermula dari proses musyawarah. Berbeda dengan Perpres No 36 Tahun 2005 jo Perpres No 65 Tahun 2006, musyawarah menurut Undang-Undang ini dilaksanakan hanya dalam waktu 30 hari. Hal tersebut diatur dalam Pasal 37 yang berbunyi sebagai berikut:

1) Lembaga Pertanahan melakukan musyawarah dengan Pihak yang Berhak dalam waktu paling lama 30 (tiga puluh) hari kerja sejak hasil penilaian dari Penilai disampaikan kepada Lembaga Pertanahan untuk menetapkan bentuk dan/atau besarnya Ganti Kerugian berdasarkan hasil penilaian Ganti Kerugian sebagaimana dimaksud dalam Pasal 34.

2) Hasil kesepakatan dalam musyawarah sebagaimana dimaksud pada ayat (1) menjadi dasar pemberian Ganti Kerugian kepada Pihak yang Berhak yang dimuat dalam berita acara kesepakatan.”

Waktu 30 hari adalah waktu yang sangat singkat apabila dibanding waktu musyawarah yang disediakan dalam Perpres No 36 Tahun 2005 jo Perpres No 65 Tahun 2006 yaitu selama 120 hari. Tentu saja terbatasnya waktu yang tersedia untuk musyawarah akan berdampak pada tercapai atau tidaknya kesepakatan besaran ganti rugi. Padahal, tahap musyawarah adalah tahap yang sangat penting dimana dalam Undang-Undang ini didasarkan pada asas Kesepakatan sebagaimana diatur dalam bab II tentang Asas dan Tujuan pasal 2, yang berbunyi:

"Pengadaan Tanah untuk Kepentingan Umum dilaksanakan berdasarkan asas:

a. kemanusiaan;

b. keadilan;

c. kemanfaatan;

d. kepastian;

e. keterbukaan;

f. kesepakatan;

g. keikutsertaan;

h. kesejahteraan;

i. keberlanjutan; dan

j. keselarasan. “

Dalam hal waktu yang disediakan sangat terbatas sedangkan besaran ganti rugi adalah suatu titik temu yang sangat sulit didapat, maka waktu yang terbatas tersebut akan membatasi pihak yang berhak dan pemerintah untuk melakukan negosiasi. Apabila selama 30 hari dilakukan musyawarah tidak tercapai kesepakatan besaran nilai ganti rugi, pihak yang berhak dapat mengajukan upaya keberatan ke pengadilan negeri dalam waktu hanya 14 hari sejak musyawarah penetapan Ganti Kerugian. Apabila dalam tahap ini pihak yang berhak tidak sepakat dengan keputusan pengadilan mengenai besaran nilai ganti rugi, maka pihak yang berhak dapat melakukan upaya keberatan ke Mahkamah Agung dalam waktu hanya 14 hari. 
Setelah tahap tersebut sudah tidak ada upaya lagi, sehingga hal tersebut adalah upaya hukum terakhir. Hal tersebut diatur dalam Pasal 38 yang berbunyi sebagai berikut:

1) Dalam hal tidak terjadi kesepakatan mengenai bentuk dan/atau besarnya Ganti Kerugian, Pihak yang Berhak dapat mengajukan keberatan kepada pengadilan negeri setempat dalam waktu paling lama 14 (empat belas) hari kerja setelah musyawarah penetapan Ganti Kerugian sebagaimana dimaksud dalam Pasal 37 ayat (1).

2) Pengadilan negeri memutus bentuk dan/atau besarnya Ganti Kerugian dalam waktu paling lama 30 (tiga puluh) hari kerja sejak diterimanya pengajuan keberatan.

3) Pihak yang keberatan terhadap putusan pengadilan negeri sebagaimana dimaksud pada ayat (2) dalam waktu paling lama 14 (empat belas) hari kerja dapat mengajukan kasasi kepada Mahkamah Agung Republik Indonesia.

4) Mahkamah Agung wajib memberikan putusan dalam waktu paling lama 30 (tiga puluh) hari kerja sejak permohonan kasasi diterima.

5) Putusan pengadilan negeri/Mahkamah Agung yang telah memperoleh kekuatan hukum tetap menjadi dasar pembayaran Ganti Kerugian kepada pihak yang mengajukan keberatan."

Maria SW Sumardjono menilai bahwa waktu 14 hari adalah waktu yang sangat singkat bagi pihak yang berhak untuk mengajukan keberatan. Sehingga apabila ketentuan tersebut tidak mendapat sosialisasi dimasyarakat, akan terjadi keributan dimasyarakat karena apabila telah lewat dari 14 hari dianggap menerima putusan pengadilan negeri. ${ }^{9}$

Selanjutnya pada tahap kasasi, ketika keputusan mahkamah agung sudah dikeluarkan, maka pada hakikatnya saat itulah pihak yang berhak sudah tidak lagi memiliki hubungan hukum dengan tanahnya karena telah hapus. Sebagaimana telah disebut diawal pembahasan sub bab ini, pengalihan hak atas tanah telah terjadi melalui keputusan pengadilan, dimana hal itu sama sekali baru. Hal tersebut diatur dalam Pasal 43 yang berbunyi:

"Pada saat pelaksanaan pemberian Ganti Kerugian dan Pelepasan Hak sebagaimana dimaksud dalam Pasal 41 ayat (2) huruf a telah dilaksanakan atau pemberian Ganti Kerugian sudah dititipkan di pengadilan negeri sebagaimana dimaksud dalam Pasal 42 ayat (1), kepemilikan atau Hak Atas Tanah dari Pihak yang Berhak menjadi hapus dan alat bukti haknya dinyatakan tidak berlaku dan tanahnya menjadi tanah yang dikuasai langsung oleh negara.”

Setelah keputusan tersebut, maka apabila pihak yang berhak menolak keputusan mahkamah agung, uang ganti rugi akan dititipkan ke pengadilan negeri setempat. Hal tersebut diatur dalam Pasal 42 yang berbunyi sebagai berikut:

1) Dalam hal Pihak yang Berhak menolak bentuk dan/atau besarnya Ganti Kerugian berdasarkan hasil musyawarah sebagaimana dimaksud dalam Pasal 37, atau putusan pengadilan negeri/Mahkamah Agung sebagaimana dimaksud dalam Pasal 38, Ganti Kerugian dititipkan di pengadilan negeri setempat.

2) Penitipan Ganti Kerugian selain sebagaimana dimaksud pada ayat (1), juga dilakukan terhadap:

a. Pihak yang Berhak menerima Ganti Kerugian tidak diketahui keberadaannya; atau

b. Objek Pengadaan Tanah yang akan diberikan Ganti Kerugian:

(1) sedang menjadi objek perkara di pengadilan;

(2) masih dipersengketakan kepemilikannya;

(3) diletakkan sita oleh pejabat yang berwenang;

(4) menjadi jaminan di bank.

9 DPR RI,. 2011. Rapat Dengar Pendapat Umum: Mendengarkan Pendapat Pakar. Jakarta: DPR RI 


\section{PENUTUP}

1. Terdapat perbedaan ruang lingkup dan tujuan hal hal yang diatur dalam Perpres No 65 Tahun 2006 dan Undang-Undang No 2 Tahun 2012. Ganti rugi yang diatur dalam Perpres No 65 Tahun 2006 adalah kerugian baik bersifat fisik dan/atau non fisik yang dapat memberikan kelangsungan hidup yang lebih baik dari tingkat kehidupan sosial ekonomi sebelum terkena pengadaan tanah. Sementara Undang-Undang No 2 Tahun 2012 yang menyatakan ganti kerugian adalah penggantian yang layak dan adil kepada pihak yang berhak dalam proses pengadaan tanah. ruang lingkup dalam Perpres No 65 Tahun 2006 meliputi fisik dan non fisik sedangkan dalam Undang-Undang No 2 Tahun 2012 tidak disebut sama sekali. Dalam hal tujuan, Perpres No 65 Tahun 2006 menginginkan terjadinya kelangsungan hidup yang lebih baik dari tingkat kehidupan sosial ekonomi sebelum terkena pengadaan tanah, sementara dalam Undang-Undang No 2 Tahun 2012 mengatur layak dan adil. Dari perbandingan tersebut dalam hal tujuan telah terjadi penurunan kemauan politik dari Pemerintah.

2. Dalam hal tidak terjadi kesepakatan ganti rugi dan lokasi pengadaan tanah tidak dapat dialihkan, Undang-Undang No 2 Tahun 2012 telah memunculkan norma baru dalam mekanisme peralihan hak atas tanah yang tidak pernah ada di peraturan perundangan sebelumnya termasuk dalam Undang-Undang Pokok Agraria. Undang-Undang No 2 Tahun 2012 telah bertentangan dengan Undang-Undang Pokok Agraria karena mekanisme yang seharusnya adalah melalui pencabutan hak. Pencabutan hak atas tanah tidak dapat dilakukan secara mudah, sementara konsinyasi dapat dilakukan melalui pengadilan negeri setempat. Pemerintah memilih jalan mudah dan singkat dalam peralihan hak atas tanah sehingga sangat rentan dengan abuse of power.

\section{DAFTAR PUSTAKA}

DPR RI. 2011. Rapat Dengar Pendapat Umum: Mendengarkan Pendapat Pakar. Jakarta: DPR RI

Muhadar. 2006. Viktimisasi Kejahatan Pertanahan, Cetakan ke II, Edisi Revisi, Yogyakarta: Laksbang Pressindo

Soerjono Soekanto, 1983. Penegakan hukum. Bandung: Bina Cipta

Subekti. 1985. Pokok-pokok Hukum Perdata. Jakarta: PT. Intermasa

Subekti, 1979. Hukum Perjanjian Cetakan ke-VI. Jakarta: PT. Intermedia

Supriadi. 2009. Hukum Agraria. Sinar Grafika: Jakarta

Sudikno Mertokusumo. 2007. Mengenal Hukum Suatu Pengantar, Revisi Ketiga. Yogyakarta: Liberty 